\title{
Fiscal decentralization and deficits: International evidence
}

\author{
Bilin Neyapti* \\ Department of Economics, Bilkent University, 06800 Bilkent, Ankara, Turkey
}

\section{A R T I C L E I N F O}

\section{Article history:}

Received 23 May 2008

Received in revised form 17 December 2009

Accepted 1 January 2010

Available online 6 January 2010

\section{JEL classification:}

E62

H62

H71

H72

\section{Keywords:}

Fiscal decentralization

Budget deficits

\section{Introduction}

Fiscal decentralization (FD) occurs through devolution of responsibilities for public spending and revenue collection from the central to local governments. FD has been a feature of economic reform programs based on the following arguments: (i) decentralization of spending increases efficiency because local governments have better local information and hence can better match policies with the preferences of citizens (Samuelson, 1954; Oates, 1972, 1993); (ii) decentralization of fiscal activity increases accountability and transparency of public good delivery (de Mello, 2000a); and (iii) taxpayers are more willing to cooperate with the accountable local governments (Wasylenko, 1987). ${ }^{1}$ Following on from these arguments, we would predict that FD decreases government deficits. With the exception of De Mello, 2000b), this prediction has not received much attention. ${ }^{2}$ De Mello (2000b) examined fiscal structures in a number of countries and reported negative effects on fiscal balances due to coordination failures in intergovernmental fiscal relations, especially in low-income countries. ${ }^{3}$ The study reported here goes beyond de Mello (2000b) in addressing the role of the institutional and structural factors that influence the relationship between FD and budget deficits and in treating separately expenditure and revenue decentralization.

\footnotetext{
* Tel.: +90312 290 2030; fax: +90312 2665140 .

E-mail address: neyapti@bilkent.edu.tr.

1 Panizza (1999), in an overview of the theoretical literature on FD, groups studies according to optimal division of powers (decentralization theorem), the role of organization costs, and competition among jurisdictions.

2 See however King and Ma (2001) and Neyapti (2004), both of which found a negative relationship between revenue decentralization and inflation. Davoodi and Zou (1998) found a negative relationship between FD and growth in less developed countries. Martinez-Vazquez and McNab (2006) view the empirical evidence on the relationship between FD and growth as mixed. Thiessen (2003) demonstrates that, for high-income OECD countries, there is an intermediate level of FD beyond which the positive growth effect disappears. Jin and Zou (2002) demonstrate that expenditure decentralization increases the size of aggregate government but revenue decentralization has the opposite effect. Kappeler and Välilä (2008) show based on European data that FD boosts the relative share of economically productive public investment such as infrastructure.

${ }^{3}$ De Mello (2000b) measures coordination failures due to common pool and agency problems by expenditure decentralization and sub-national revenue autonomy and dependency.
} 
An investigation of the effects of FD on budget deficits should address both expenditure and revenue aspects of FD. The literature emphasizes that decentralization of fiscal expenditures may increase the efficiency of local public good delivery when a country is large, heterogeneous, or ethno-linguistically fractionalized because it is especially in these cases that local governments are in a better position than the central government to assess local preferences. ${ }^{4}$

While decentralizing budgetary spending may be efficiency enhancing, expenditure and revenue decentralization can have drawbacks. Local governments may have limited tax bases or fail to take full advantage of existing tax bases, and local debt issuance and management capacity may be limited. ${ }^{5}$ Limited revenue autonomy of local governments implies that their expenditure autonomy is also limited, making local governments mere spending units of central governments. The common pool problem arising from not-fully internalized costs of local fiscal actions may lead fiscal imbalances to increase. These disadvantages may be so great as to outweigh the increased likelihood of taxpayer compliance in revenue collection when fiscal activity is decentralized. Moreover, FD without an effective central redistributive system may result a more unequal income distribution if revenue bases vary across regions (see, for example, Zhang, 2006 and Bouton et al., 2008).

There are various arguments against expenditure decentralization. First, local governments may lack of economies of scale in the provision of public goods; information and coordination costs may be higher for local governments because of lack of institutional and administrative capacity. ${ }^{6}$ Secondly, if local vested interests are powerful, decentralization may increase corruption and social fragmentation in the absence of local accountability. ${ }^{7}$ Thirdly, decentralization may increase competition and political tension among local governments. Fourthly, coordination problems across different tiers of the government may lead to a deficit bias and thus hinder fiscal reforms and implementation of macroeconomic adjustment. Finally, the central government may unable to credibly commit to a hard-budget constraint (no bailout of the local government) due to political concerns (Goodspeed, 2002). The literature therefore proposes arguments both in favor and against the effectiveness of fiscal decentralization in improving fiscal performance. ${ }^{8}$ Tanzi (2000) notes that the effectiveness of FD in improving allocative efficiency depends on such factors as the size of country, the extent of privatization in the economy; ability of local governments to raise revenue; transparency; and local administrative and institutional capacity. ${ }^{9}$

In view of the foregoing arguments and the common pool problem (see Hillman, 2009 chapter 9), decentralization of fiscal activity is predicted to increase the fiscal burden. This problem can in principle be limited or eliminated through local accountability and "good governance". Efficiency gains of fiscal decentralization in large heterogeneous countries may compensate for the increase in the spending bias. I account for structural and institutional factors, including country size, quality of governance, local accountability, and the extent of ethnolinguistic fractionalization and test the hypothesis that the disciplining effect of FD is conditioned by these factors.

The evidence presented in this paper provides strong support for the hypothesis that both expenditure and revenue decentralization reduce budget deficits. The effectiveness of fiscal decentralization in reducing deficits is enhanced by greater population, although deficits increase with population size on average. There is also suggestive evidence that the benefits of FD through fiscal discipline increase when governance and local accountability are inadequate. Ethnolinguistic fractionalization enhances the effectiveness of revenue decentralization in achieving fiscal discipline but not expenditure decentralization. Output growth, income levels, and governance and local accountability reduce budget deficits. The impact of the size of the government is significantly positive, as expected. These results generally survive robustness tests.

The structure of the paper is as follows. Section 2 presents the data and methodology. Section 3 reports the empirical findings. Section 4 concludes.

\section{Data and methodology}

Sub-national levels of government are not uniform across countries. For consistency, this study takes the sum of local and state and provincial levels of government where both available as the indicator of sub-national government activity. ${ }^{10}$ Expenditure decentralization is measured as the share in total government spending of the spending of both state and provincial governments and local governments (FDexp). Revenue decentralization (FDrev) is measured in the same manner, using data on revenues

\footnotetext{
4 Adam et al. (2008) provide evidence in favor of increased public sector efficiency associated with FD in the OECD region. Kyriacou and Sagales (2009) show that the evidence regarding FD's effect on government efficiency depends on countries' level of development and institutional characteristics.

5 There may be legally imposed limitations on sub-national borrowing in some cases.

6 See, for example, Blanchard and Shleifer (2000), and Bradhan and Mookherjee (1998).

7 Based on a study of Russian case, Fleinkman and Pleakanov (2005) observe that decentralization distorts incentives particularly in rentier regions, and propose a higher degree of intraregional decentralization in such regions.

8 Among the empirical cross-sectional studies, de Mello (2000a) shows that higher social capital, defined as confidence in government, civic cooperation and associational activity, is positively related with fiscal decentralization. De Mello and Barenstein (2001) also find evidence that good governance is positively related with sub-national spending levels, and the higher are non-tax revenues the stronger is this relationship. Fisman and Gatti (2002) find a strong negative relationship between expenditure decentralization and corruption, although Treisman (2000) observes no significant relationship between the two variables, due possibly to different measures of corruption and inclusion of more control variables. Based on the case of China, Chen (2004) argues that revenue decentralization may lead to a helping-hand form of corruption. Case studies on the effects of FD are generally inconclusive (see, for example, Barrett, 2000; Dethier, 2000; Eaton, 2001; Faguet, 2001; Feltenstein and Iwata, 2005; Hope, 2000; Lin and Liu, 2000; Neyapti, 2005; Norris et al., 2000).

${ }^{9}$ See for example Panizza (1999), Von Braun and Grote (2002), and De Mello (2000a). Tanzi (2008) argues that historical and global developments are important for determining optimal fiscal arrangements (see also Vaubel, 2009, and Tanzi, 2009). Stegarescu (2009) proposes that integration has increased FD in the OECD region.

10 For a check of robustness, I also repeated the regression analysis using two other alternative definitions of decentralization: $\mathrm{i}$ ) the ratio of state and provincial government expenditure (or revenues) to the total of central and state and provincial expenditures (or revenues) and ii) the ratio of local spending (or revenues) to the total of central and local expenditures (or revenues). The results of those regressions are discussed.
} 
instead of expenditures. ${ }^{11}$ The main source of these data, detailed descriptions of which are provided in Appendix 1, is the Government Financial Statistics of the IMF.

Drawing on the discussions by Oates (1972) and Panizza (1999), I focus on the "decentralizable" part of fiscal spending to correctly measure the extent of decentralization; social security and defence spending are considered to account for the main part of non-decentralizable government spending. Because social security spending is larger in high-income than low-income countries, the exclusion of this component avoids a potential bias in the results. ${ }^{12}$

The data covers up to 19 years of observation, ranging from 1980 to 1998 , for 16 countries. ${ }^{13}$ The panel is unbalanced and the number of observations is 172 and 203 for the estimations of FDexp and FDrev, respectively. ${ }^{14}$ The estimations are separately run for FDexp and FDrev. ${ }^{15}$

Based on the above descriptions of FDexp and FDrev, the following models are estimated, where FD is used as a generic notation to refer to either FDexp or FDrev:

$$
(D e f / G D P)_{i t}=\alpha_{0}+\alpha_{1} F D_{i t}+\alpha_{2}\left(F D_{i t}{ }^{*} I_{i j}\right)+\alpha_{3} G_{i t}+\alpha_{4} G D P g r_{i t}+\alpha_{5} G N I p c_{i j}+\alpha_{6} I_{i j}+\varepsilon_{i t}
$$

The subscript it stands for country $i$ at time t. Def/GDP stands for general government budget deficits in percentages of GDP; $G$ is the ratio of general government expenditures in GDP; GDPgr is the growth in real GDP; and GNIpc is the (log of) per capita gross national income. $G$ is added to the estimation since government size is often argued to cause inefficiency and thus higher deficits. GDPgr is added to control for business cycles since they also have potential to affect the size of deficits. ${ }^{16}$ GNIpc is used as a proxy for the level of development.

$I_{i j}$ in the above model stands for the various country-specific and institutional characteristics, denoted by subscript $j$, that hardly change over time but changes across countries. Those characteristics (j's) that the literature suggests to be related with the outcomes of FD are: country size, proxied by population (pop); the extent of ethnolinguistic fractionalization (ethnoling); governance indicators and; local accountability (locelec), which is proxied by a dummy that takes the value of one in case local elections exist and zero otherwise. The average of the six indices of Kaufmann et al. (2002), namely, control of corruption; rule of law; political instability; governmental efficiency; voice and accountability; and regulatory quality, are used as a measure of governance (Gov). ${ }^{17}$ Each of these variables ( $I_{j}$ 's where $j=1$ to 4 ) are rescaled to numbers that range between 0 and 1 (see Appendix 1 for explanations and Appendix 2 for summary statistics). The resulting four indices, $I_{p o p} ; I_{\text {ethnoling}} ; I_{\text {locelec }}$ and $I_{g o v}$, are used to measure a country's structural and institutional characteristics. These indices are used both as control variables and in interaction with the FD terms as the main hypothesis of the current paper is that they influence the effectiveness of FD in reducing deficits. ${ }^{18}$

Brambor et al. (2006) point out that the marginal effect of FD on Def/GDP should be observed by constructing confidence intervals for the estimates of $\left(\alpha_{1}+\alpha_{2}\right)$ over the possible values of $I_{j}$. If the interval lies above (below) the zero line, then the effect is significantly positive (negative). ${ }^{19}$ Hence, one can identify the range of $I_{j}$ values for which the effect of FD can be said to be significant. The authors show that even when the coefficient $\alpha_{2}$ is insignificant, it is possible to have a significant marginal effect of FD for a substantive range of $I_{j}$ values. In the next section, I adopt this method to evaluate the effects of FD on deficits.

\subsection{Model specification}

Noting the limited country coverage of the panel due to data deficiencies, a fixed effects model is not a preferred method of estimation (see, for example, Kennedy, 1997). A fixed effects model is inappropriate also because some of the key right hand side variables are invariant over time. On the other hand, random effects specification is also rejected based on the Hausman test results. ${ }^{20}$

\footnotetext{
${ }^{11}$ I do not account for idiosyncracies in fiscal accounts across countries with regard to the extent of the separation of local revenue collection authority and expenditure autonomy from the central government. The data may therefore have measurement problems, such as in case of shared revenues or grants appearing as own revenues of local governments in some countries, leading to a possible positive bias in the measurement of revenue decentralization.

${ }_{12}$ Once the social security and defence components of government spending are excluded, indicators of expenditure decentralization appear much higher in high-income than low-income countries.

${ }^{13}$ The country list consists of: Austria, Australia, Bolivia, Brazil, Canada, Colombia, France, Germany, Iran, Malaysia, Mexico, Portugal, South Africa, Spain, Switzerland and the US.

${ }^{14}$ In the regressions estimated with FDrev, the number of observations rises to 220 and 206 when using state and provincial level of data and local government level data, respectively. The number of observations in the regressions estimated with FDexp does not change across alternative definitions.

${ }^{15}$ While the FD terms are both negatively significant in the separate regressions (using a basic model that employs the rest of the control variables but not the interactive terms), when both are employed in the regression FDrev is positive and significant, due possibly to high collinearity between FDrev and FDexp (0.91).

${ }^{16}$ The data source for these variables is International Financial Statistics of the IMF.

17 The estimates for each of all the six governance variables are based on an analysis of wide-ranging data sources - comprised of both polls and surveys conducted in individual countries (see, Kaufmann et al., 2002).

${ }_{18}$ Brambor et al. (2006) show that, to avoid inconsistencies in the estimation, it is necessary to include all of the constitutive terms in the regression that involves multiplicative interaction terms, as is done for the FD terms in this paper.

${ }_{19}$ Brambor et al. (2006) show that it is incorrect to decide on the inclusion of the interactive term simply by looking at the significance of the coefficient of the interactive variable.

${ }^{20}$ Hausman (1978) proposes a test for the correlation between individual effects and explanatory variables. The null hypothesis is that, assuming that both OLS and GLS are consistent, OLS is inefficient, the alternative being OLS is consistent but GLS is not. Rejection of the null hypothesis thus leads to the rejection of random effects model, in favor of fixed effects (see Hsiao, 1986, Greene, 1993, or Baltagi, 1995). The null hypothesis of random effects specification being consistent is rejected at $1 \%$ level of significance; for the baseline model, reported in column 1 of both Tables 1 and 2, the Chi-Square Test is 288.9 for FDexp and 20.9 for FDrev, both significant at $1 \%$ level.
} 
Table 1

Estimation results with expenditure decentralization (FDexp).

\begin{tabular}{|c|c|c|c|c|c|c|}
\hline \multicolumn{7}{|c|}{ Dependent variable: budget deficits/GDP } \\
\hline \multicolumn{7}{|c|}{ Method: OLS with robust standard errors } \\
\hline Explanatory variables: & I & II & III & IV & V & VI \\
\hline Constant & $\begin{array}{l}0.14^{* * *} \\
(6.16)\end{array}$ & $\begin{array}{l}0.14^{* * *} \\
(6.28)\end{array}$ & $\begin{array}{l}0.14^{* * *} \\
(5.32)\end{array}$ & $\begin{array}{l}0.32^{* * *} \\
(5.48)\end{array}$ & $\begin{array}{l}0.22^{* * *} \\
(5.31)\end{array}$ & $\begin{array}{l}0.16^{* * *} \\
(5.55)\end{array}$ \\
\hline Trend & $\begin{array}{l}-0.001^{* * *} \\
(-4.03)\end{array}$ & $\begin{array}{l}-0.001^{* * *} \\
(-5.00)\end{array}$ & $\begin{array}{l}-0.001^{* *} \\
(-2.47)\end{array}$ & $\begin{array}{l}-0.001 \\
(-1.59)\end{array}$ & $\begin{array}{l}-0.001^{* *} \\
(-2.23)\end{array}$ & $\begin{array}{l}-0.002^{* * *} \\
(-3.72)\end{array}$ \\
\hline Exp. Decentr.(FDexp) & $\begin{array}{l}-0.08^{* * *} \\
(-5.38)\end{array}$ & $\begin{array}{l}-0.09^{* * *} \\
(-5.00)\end{array}$ & $\begin{array}{l}-0.07^{* * *} \\
(-3.05)\end{array}$ & $\begin{array}{l}-0.42^{* * *} \\
(-4.35)\end{array}$ & $\begin{array}{l}-0.35^{* * *} \\
(-4.60)\end{array}$ & $\begin{array}{l}-0.17^{* * *} \\
(-5.08)\end{array}$ \\
\hline FDexp-extreme & & $\begin{array}{l}0.02^{*} \\
(1.91)\end{array}$ & $\begin{array}{l}0.02^{* *} \\
(2.19)\end{array}$ & $\begin{array}{l}0.01 \\
(1.27)\end{array}$ & $\begin{array}{l}0.03^{* *} \\
(2.79)\end{array}$ & $\begin{array}{l}0.01 \\
(1.13)\end{array}$ \\
\hline G & $\begin{array}{l}0.21^{* * *} \\
(7.82)\end{array}$ & $\begin{array}{l}0.22^{* * *} \\
(8.05)\end{array}$ & $\begin{array}{l}0.25^{* * *} \\
(8.46)\end{array}$ & $\begin{array}{l}0.28^{* * *} \\
(9.62)\end{array}$ & $\begin{array}{l}0.25^{* * *} \\
(8.20)\end{array}$ & $\begin{array}{l}0.26^{* * *} \\
(8.58)\end{array}$ \\
\hline GDP gr & $\begin{array}{l}-0.001^{* *} \\
(-2.15)\end{array}$ & $\begin{array}{l}-0.001^{* * *} \\
(-2.18)\end{array}$ & $\begin{array}{l}-0.001 \\
(-1.42)\end{array}$ & $\begin{array}{l}-0.001 \\
(-1.51)\end{array}$ & $\begin{array}{l}-0.001^{* *} \\
(-2.15)\end{array}$ & $\begin{array}{l}-0.001^{* *} \\
(-2.10)\end{array}$ \\
\hline $\log (\mathrm{GNIpc})$ & $\begin{array}{l}-0.02^{* * *} \\
(-4.07)\end{array}$ & $\begin{array}{l}-0.01^{* * *} \\
(-4.08)\end{array}$ & $\begin{array}{l}-0.02^{* * *} \\
(-4.31)\end{array}$ & $\begin{array}{l}-0.03^{* * *} \\
(-4.49)\end{array}$ & $\begin{array}{l}-0.02^{* * *} \\
(-4.01)\end{array}$ & $\begin{array}{l}-0.01^{* * *} \\
(-2.29)\end{array}$ \\
\hline FDexp * population & & & $\begin{array}{l}-1.06^{* * *} \\
(-3.46)\end{array}$ & & & \\
\hline FDexp* governance & & & & $\begin{array}{l}0.43^{* * *} \\
(3.43)\end{array}$ & & \\
\hline FDexp* local elec.dummy & & & & & $\begin{array}{l}0.25^{* * *} \\
(2.80)\end{array}$ & \\
\hline FDexp* ethnoling.frac. & & & & & & $\begin{array}{l}0.13^{* * *} \\
(3.04)\end{array}$ \\
\hline Population & & & $\begin{array}{l}0.78^{* * *} \\
(4.22)\end{array}$ & $\begin{array}{l}0.22^{* * *} \\
(8.13)\end{array}$ & $\begin{array}{l}0.18^{* * * *} \\
(7.50)\end{array}$ & $\begin{array}{l}0.16^{* * *} \\
(7.30)\end{array}$ \\
\hline Governance & & & $\begin{array}{l}0.05 \\
(1.53)\end{array}$ & $\begin{array}{l}-0.10^{* * *} \\
(-2.61)\end{array}$ & $\begin{array}{l}-0.03^{* * *} \\
(-2.14)\end{array}$ & $\begin{array}{l}-0.03 \\
(0.94)\end{array}$ \\
\hline Local elections & & & $\begin{array}{l}-0.02^{*} \\
(-1.74)\end{array}$ & $\begin{array}{l}0.01 \\
(0.55)\end{array}$ & $\begin{array}{l}-0.03^{* * *} \\
(-2.14)\end{array}$ & $\begin{array}{l}-0.01 \\
(-1.19)\end{array}$ \\
\hline Ethnoling.Frac. & & & $\begin{array}{l}0.004 \\
(0.56)\end{array}$ & $\begin{array}{l}-0.03^{* * *} \\
(-2.90)\end{array}$ & $\begin{array}{l}-0.01 \\
(-1.30)\end{array}$ & $\begin{array}{l}-0.05^{* *} \\
(-2.29)\end{array}$ \\
\hline Adjusted $R$-square & 0.41 & 0.42 & 0.57 & 0.57 & 0.55 & 0.55 \\
\hline Wald test for the FD terms & & $30.28^{* * *}$ & $13.84^{* * *}$ & 0.48 & $13.63^{* * *}$ & $2.83^{*}$ \\
\hline Number of countries & 16 & 16 & 16 & 16 & 16 & 16 \\
\hline Number of observations: & 177 & 177 & 177 & 177 & 177 & 177 \\
\hline
\end{tabular}

Notes: Figures in parentheses are the $t$-ratios

${ }^{* * *},{ }^{* *}$ and ${ }^{*}$ indicate significance at $1 \%, 5 \%$ and $10 \%$ levels, respectively.

To investigate the stationary of the basic model (reported in column 1 of Tables 1 and 2), Levin-Lin-Chu (LLC) tests, assuming homogenous unit root processes, are performed for each of the model variables. ${ }^{21}$ After correcting for serial correlation and using the lag lengths according to the Schwartz Information Criteria (SCI), LLC-test results (see Appendix 4) indicate that, the FD terms are trend-stationary. Accordingly, a trend term was added to estimate the above specification.

To explore the endogeneity of the FD terms, the Hausman test of endogeneity is employed. To this end, FDexp (FDrev) is regressed on all the right hand side variables and lagged deficits. This exercise reveals that in many of the specifications involving different $I_{j}$ 's and FD terms either the lagged deficit term is insignificant or only marginally significant, or the inclusion of the residuals from this first stage regression reveals no significant effect, or both. ${ }^{22}$ As a result, in what follows FD is treated as an exogenous variable, where the estimations are conducted using OLS with heteroscedasticity correction in the error terms. ${ }^{23}$

\section{Estimation results}

In this section, the main hypothesis of the paper, that fiscal decentralization has a significant relationship with budget deficits especially under certain structural and institutional conditions, is tested using both expenditure (FDexp) and revenue measures of fiscal decentralization (FDrev).

Tables 1 and 2 report the estimation results of the model for FDexp and FDrev as the dependent variable, respectively. Columns I and II in both tables report a version of the above model excluding the $I_{j}$ terms so as to mark the improvements in the explanatory power of the model brought about by the addition of these terms, which are reported in the subsequent columns. Column II

\footnotetext{
21 Maddala (1998) reports that LL-test, and not the IPS test, is appropriate for panels that are unbalanced as the one employed in the current paper.

22 The results are available from the author upon request.

${ }^{23}$ In addition to correcting for heteroscedasticity, estimations that also allow for autocorrelation correction has been performed, leading to slightly weaker but virtually the same results as those currently reported in the paper.
} 
Table 2

Estimation results with revenue decentralization (FDrev).

\begin{tabular}{|c|c|c|c|c|c|c|}
\hline \multicolumn{7}{|c|}{ Dependent variable: budget deficits/GDP } \\
\hline \multicolumn{7}{|c|}{ Method: OLS with robust standard errors } \\
\hline Explanatory variables: & I & II & III & IV & V & VI \\
\hline \multirow[t]{2}{*}{ Constant } & $0.17^{* * *}$ & $0.18^{* * *}$ & $0.16^{* * *}$ & $0.18^{* * *}$ & $0.22^{* * *}$ & $0.16^{* * *}$ \\
\hline & $(7.62)$ & $(8.75)$ & $(5.94)$ & $(4.22)$ & $(6.72)$ & $(5.11)$ \\
\hline \multirow[t]{2}{*}{ Trend } & $-0.001^{* * *}$ & $-0.001^{* * *}$ & $-0.001^{* * *}$ & $-0.002^{* * *}$ & $-0.001^{* * *}$ & $-0.002^{* * *}$ \\
\hline & $(-4.94)$ & $(-4.82)$ & $(-5.22)$ & $(-5.17)$ & $(-4.59)$ & $(-5.49)$ \\
\hline \multirow[t]{2}{*}{ Rev. Decentr.(FDrev) } & $-0.03^{* *}$ & $-0.07^{* *}$ & -0.04 & -0.12 & $-0.41^{* * *}$ & -0.07 \\
\hline & $(-2.07)$ & $(-2.89)$ & $(-1.16)$ & $(-1.15)$ & $(-4.79)$ & $(-1.50)$ \\
\hline \multirow[t]{2}{*}{ FDrev-extreme } & & $0.04^{* * *}$ & 0.02 & 0.02 & 0.002 & 0.01 \\
\hline & & $(2.68)$ & (1.18) & $(0.66)$ & $(0.10)$ & $(0.51)$ \\
\hline \multirow[t]{2}{*}{ G } & $0.20^{* * *}$ & $0.21^{* * *}$ & $0.25^{* * *}$ & $0.26^{* * *}$ & $0.24^{* * *}$ & $0.26^{* * *}$ \\
\hline & $(8.33)$ & (9.15) & (9.67) & $(10.03)$ & $(9.24)$ & (9.77) \\
\hline \multirow[t]{2}{*}{ GDP gr } & -0.001 & -0.001 & -0.001 & -0.001 & $-0.001^{* *}$ & -0.001 \\
\hline & $(-1.59)$ & $(-1.54)$ & $(-1.38)$ & $(1.53)$ & $(2.01)$ & (1.59) \\
\hline \multirow[t]{2}{*}{$\log (\mathrm{GNIpc})$} & $-0.02^{* * *}$ & $-0.02^{* * *}$ & $-0.02^{* * *}$ & $-0.02^{* * *}$ & $-0.02^{* * *}$ & $-0.01^{* *}$ \\
\hline & $(-5.86)$ & $(-6.55)$ & $(-3.71)$ & $(-3.15)$ & $(-4.42)$ & $(-2.47)$ \\
\hline FDrev* population & & & $\begin{array}{r}-0.69^{*} \\
(-1.88)\end{array}$ & & & \\
\hline FDrev* governance & & & & $\begin{array}{c}0.09 \\
(0.65)\end{array}$ & & \\
\hline FDrev*local elec.dummy & & & & & $\begin{array}{l}0.40^{* * *} \\
(3.88)\end{array}$ & \\
\hline FDrev* ethnoling.frac. & & & & & & $\begin{array}{c}-0.04 \\
(-0.64)\end{array}$ \\
\hline \multirow[t]{2}{*}{ Population } & & & $0.40^{* * *}$ & $0.15^{* * *}$ & $0.15^{* * *}$ & $0.14^{* * *}$ \\
\hline & & & $(2.64)$ & $(5.08)$ & $(6.22)$ & $(6.57)$ \\
\hline \multirow[t]{2}{*}{ Governance } & & & -0.02 & $-0.06^{* *}$ & -0.02 & $-0.05^{* *}$ \\
\hline & & & $(0.91)$ & $(-2.12)$ & $(0.65)$ & $(-1.95)$ \\
\hline \multirow[t]{2}{*}{ Local elections } & & & $-0.02^{* *}$ & $-0.01^{*}$ & $-0.05^{* * *}$ & -0.01 \\
\hline & & & $(-2.22)$ & $(-1.69)$ & $(-3.75)$ & $(-1.56)$ \\
\hline \multirow[t]{2}{*}{ Ethnoling.Frac. } & & & -0.001 & -0.01 & -0.001 & -0.01 \\
\hline & & & $(-0.20)$ & $(-0.73)$ & $(-0.09)$ & $(-0.79)$ \\
\hline Adjusted $R$-square & 0.35 & 0.36 & 0.48 & 0.47 & 0.48 & 0.47 \\
\hline Wald test for the FD terms & & & $3.91^{* *}$ & 0.25 & 0.83 & 0.80 \\
\hline Number of countries & 15 & 15 & 15 & 15 & 15 & 15 \\
\hline Number of observations: & 209 & 209 & 209 & 209 & 209 & 209 \\
\hline
\end{tabular}

Notes: Figures in parentheses are the $t$-ratios.

${ }^{* * *},{ }^{* *}$ and ${ }^{*}$ indicate significance at $1 \%, 5 \%$ and $10 \%$ levels, respectively.

reports the results of this basic model after including an additional term, FDexp-Extreme (and FDrev-Extreme), that stands for the "extreme values" of FD. ${ }^{24}$ This modification is made to explore the potentially different effects of high and low values of FD on deficits. In view of the significance of this term, it is kept for the rest of the regressions.

Due to the high level of collinearity among the interaction terms $I_{j}$ (see Appendix 3), the regressions in columns III to VI are reported with one interaction term at a time. ${ }^{25}$ Based on Brambor et al. (2006), Appendix 5a and 5b provide the plots of 95\% confidence intervals for the marginal effects of FDexp and FDrev on deficits, respectively, in case of the four $I_{i j}$ terms, each of which is measured within the interval of $[0,1]$ as described in the previous section.

The results reported in Columns I and II of both Tables 1 and 2 primarily indicate that both FDexp and FDrev have negative and significant effects on deficits. Following Thiessen (2003), the extreme values of both FDexp and FDrev are also included in the estimation, although their positive effect on deficits is not robustly significant. In all the regressions reported in Tables 1 and 2 , the size of the government $(G)$, the trend term, the level of economic development $(\log (G N I p c)$ ), and economic growth (GDPgr) have a significant effect in the expected directions: the first being positive and the rest being negative, although the significance of GDPgr is not robust. In addition, direct effects on deficit of both the population size and the local elections dummy are significant, where the sign of the first one is positive and of the latter one is negative. ${ }^{26}$

\footnotetext{
24 Extreme values of FD are selected by adding and subtracting one standard deviation to the median values of the respective FD measure observed in the current sample. Hence, the extreme values are those above 0.60 and below 0.20 for FDexp, and above 0.35 and below 0.05 for FDrev. Alternatively, the square of the FD term is used in order to explore the non-linearity in the effect of FD, as was originally done in Thiessen (2003). This alternative yields very similar results to those with the extreme values. Since the squared term is highly correlated with the actual series (97\%), however, I prefer to report the results with the extreme values in order to single out the effects of relatively high or relatively low values of FD.

${ }^{25}$ Appendix 3 shows that most of the interactive terms, indicated by shaded cells, exhibit correlations both with each other and with the FD terms by more than $80 \%$.

26 The variability for the local election dummy comes from the less developed sample, where the negative sign may imply moral hazard.
} 
The most interesting contribution of the current study is the interpretation of the interactive terms. The graphs in Appendix 5a, constructed on the basis of the reported coefficient estimates and their variance/covariance matrices, lead to the following observations. The higher the size of the population, the higher is the deficit reducing effect of FDexp. ${ }^{27}$ While for all possible ranges of ethnolinguistic fractionalization FDexp has a deficit reducing effect, this effect declines with the extent of ethnic fractionalization, possibly due to the disadvantages of increased competition among the heterogeneous groups. ${ }^{28}$

For the most part of the possible range of governance measures, FDexp has a deficit reducing effect; however, this effect declines as governance improves. Good governance already has a negative effect on deficits and FDexp has less and less marginal contribution to this effect as governance improves. Similar to the case of governance, it appears that the presence of local elections already accounts for low deficits and FDexp does not contribute to this effect, at least in the sample investigated in this paper. Noting that the variation for the local elections dummy arises due to the set of less developed countries only, an alternative explanation can be that the presence of local elections coupled with FD may induce moral hazard in the form of lower tax collection incentives for local governments so as to increase their reelectability. ${ }^{29}$

Investigation of the corresponding graphs for FDrev, as shown in Appendix 5b, reveals the following observations. As in the case of FDexp, FDrev has a significant deficit reducing effect for all possible ranges of values of population, and this effect increases the greater the size of population. The impact of having local elections on the deficit reducing effect of FDrev is similar to the case of FDexp. ${ }^{30}$ Unlike FDexp, however, the deficit reducing effect of FDrev is not affected by either gov or ethnoling.

\subsection{Testing robustness with alternative measures of FD}

As a separate experiment, a combined measure of FDexp and FDrev is formed by simple averaging of these two measures (call it FD). Using this measure, estimations yield the same findings as above for the case of population; in addition, however, ethnolingusitic fractionalization, governance and local elections now all appear to contribute to the effectiveness of FD in reducing deficits. ${ }^{31}$

In another experiment with variable definitions, instead of the extreme values of FD, the effect of only the extremely high values of FD on budget deficits is investigated. This experiment leaves the formerly reported results virtually unchanged.

The regressions reported above are also repeated using "state and provincial" and "local" data, separately. ${ }^{32}$ The results of these regressions, especially in the case of state and provincial level data, are mostly similar to the results reported above, and therefore are not reported. ${ }^{33}$ The differences from the previously reported findings are as follows. Using only local level data, local elections do not appear to matter for the effectiveness of FDexp, whereas the effectiveness of FDrev increases with ethnoling and decreases with gov. With the state and provincial level data, the only difference observed is the significant effect of lower values of ethnoling on the effectiveness of FDrev. In conclusion, these exercises robustly reveal that the effectiveness of FD in reducing deficits increases with the size of population.

Stegarescu (2005) argues that the share of sub-national spending (or revenues) in general government spending (or revenues) is potentially a problematic measure of fiscal decentralization since it does not necessarily reflect the actual assignment of fiscal resources and responsibilities to the sub-national units of the government. This author therefore proposes alternative measures of both tax and revenue decentralization (RD) that incorporates legal aspects of fiscal decision making. Comparing FDrev with Stagerascu's measures of RD for four countries reveals that FDrev exhibits a downward bias in comparison with RD2 and RD3 for three of them. ${ }^{34}$ While the current analysis does not employ Stegarescu's measures partly due to insufficient match between the two data sets, replicating this study using those measures may be a subject for future research.

As noted in Ebel and Yilmaz (2002) and Stegarescu (2005), grants and transfers can be mechanism for the central government to exercise control over sub-national decisions. In order to obtain measures of fiscal decentralization that potentially eliminate such biases, ${ }^{35}$ I replicated the estimations after adjusting the current measures of FD by subtracting grants from revenues and transfers from expenditures of both the sub-national and general government. This adjustment reduces the number of data points by 28 for both of the resulting measures of fiscal decentralization (expdec and revdec). The FD measures used in the current study are generally higher than these adjusted measures, although the magnitude of biases is not notable in many cases. ${ }^{36}$ The marginal

\footnotetext{
27 To control for the size of the country, I alternatively used the area of the country (also normalized between 0 and 1 , like the other $I_{j}$ terms). The results are virtually the same as in case of population and are therefore not reported.

${ }^{28}$ The negative direct effect of $I_{\text {ethnoling }}$ is due to the LDC sample only; a reverse effect is observed in the DC sub-sample. These results are available from the author upon request.

29 The dummy takes the value of 1 for all developed countries in the sample.

30 Note that the variation for the local elections dummy comes from the less developed countries only; it takes the value of 1 for all developed countries in the sample.

31 These results are available from the author upon request.

32 The number of observations in regressions where FDrev is used rises to 226 and 212, respectively, when state and provincial level data and local level of government data are used. The number of observations in the regressions using the alternative definitions of FDexp does not change.

${ }^{33}$ One exception is that the formerly observed anomalous positive coefficient of FDrev in interaction with $I_{\text {gov }}$ is no more significant in regressions using both state-provincial and local level data.

34 A comparison for a subset of observations identified in view of Table A3 of Stegarescu (2005) can be seen in Appendix 6.

35 IMF-GFS does not provide data that distinguish between conditional/unconditional or rule-based versus discretionary grants or transfers.

36 Data on grants and transfers are missing for Iran and Mexico, in addition to several yearly observations for the other countries in the list. Calculated differences between FD measures and Stegarescu's measures, which are available from the author upon request, are of the order of less than 0.01.
} 
effects of both expdec and revdec are observed to increase in the population size, as has been reported earlier, while the other variables do not seem to affect their effectiveness. If the adjusted measures are indeed more unbiased estimates of fiscal decentralization, these findings strengthen the observation that the effectiveness of both types of fiscal decentralization increases with the size of population.

\section{Conclusions}

The research on the relationship between socio-economic variables and fiscal decentralization (FD) has been rather inconclusive about the benefits of FD. The current paper is the first to investigate the effect of FD on government budget deficits in a panel sample, explicitly accounting for the structural and institutional factors that the literature suggests affect this relationship.

The evidence that has been presented reveals a significant negative effect of fiscal decentralization on deficits. The findings however also caution about an unconditional policy recommendation of fiscal decentralization, as the evidence also reveals that country characteristics and institutional features significantly influence the effectiveness of fiscal decentralization in reducing deficits. The current study indicates that the effectiveness of fiscal decentralization in reducing deficits is enhanced by the size of population, even though deficits, on average, are positively associated with population size.

The results also draw attention to the following observations. While expenditure decentralization is more effective in case of low degrees of ethnolinguistic fractionalization and governance, these features do not seem to influence the effectiveness of revenue decentralization. FD also seems to be more effective in the absence of local elections, which may be associated with moral hazard in less developed countries. Because different specifications of the FD variables reveal different effects of ethnolinguistic fractionalization, governance, and local elections on the effectiveness of FD, deriving policy conclusions may require further analysis in larger samples.

\section{Acknowledgements}

I have benefited from the comments of George Clarke, Lewis Davis, Andrew Feltenstein and Adam Posen. I am also grateful to Aysu Insel as well as three anonymous referees for their comments and suggestions for improvements to the paper.

\section{Appendix 1. Variable descriptions and sources}

\begin{tabular}{|c|c|c|}
\hline Deficit/GDP & Overall deficits (\% of GDP) & IMF - International Financial Statistics \\
\hline Exp. Decentr.(FDexp) & $\begin{array}{l}\text { Expenditure decentralization: } \\
=\text { (total expenditures of state, provincial and local governments)/ } \\
\text { (total government spending - social security, } \\
\text { welfare and defence spending) }\end{array}$ & IMF -Government Financial Statistics \\
\hline Rev. Decentr.(FDrev) & $\begin{array}{l}\text { Revenue decentralization: } \\
=\text { (total revenues of state, provincial and local governments)/ } \\
\text { (total government revenues ) }\end{array}$ & IMF -Government Financial Statistics \\
\hline$G / G D P$ & $=$ Total government spending/GDP & IMF - International Financial Statistics \\
\hline GDPgr & GDP growth rate (constant LCU) & IMF - International Financial Statistics \\
\hline GNIpc & $=($ Log of $)$ gross national income per capita & IMF - International Financial Statistics \\
\hline Population $\left(I_{p o p}\right)$ & $\begin{array}{l}\text { Index of population } \\
=(\text { Population/ } 1 \text { billion, such that all values in the sample range } \\
\text { between } 0 \text { and } 1)\end{array}$ & World Bank, WDI \\
\hline Governance $\left(I_{\text {gov }}\right)$ & $\begin{array}{l}\text { Average of the "normalized" indices of } 6 \text { governance indicators. } \\
\text { The individual indices are "normalized" between } 0 \text { and 1, where } \\
1 \text { corresponds to the largest value for each of the } 6 \text { indicators } \\
\text { among the original set of } 102 \text { countries. }\end{array}$ & Kaufmann et al. (2002) \\
\hline Local elections ( $\left.I_{\text {locelec }}\right)$ & $\begin{array}{l}\text { Dummy variable } \\
=(1 \text { if local/state governments locally elected; }=0 \text {, otherwise }) .\end{array}$ & $\begin{array}{l}\text { Beck et al. (2001); also see Database of } \\
\text { Political Institutions, The World Bank. }\end{array}$ \\
\hline Ethnoling.Frac. ( $I_{\text {ethnoling }}$ ) & $\begin{array}{l}\text { Index of ethnolinguistic fractionalization } \\
\text { The numbers are "normalized" between } 0 \text { and } 1 \text {, where } \\
1 \text { corresponds to 93, the largest value (Tanzania) among the } \\
102 \text { countries in the original data set. }\end{array}$ & Easterly and Levine (1997) \\
\hline
\end{tabular}

Note: calculations are available upon request from the author. 
Appendix 2. Data coverage and summary statistics

\begin{tabular}{|c|c|c|c|c|c|c|c|c|c|c|}
\hline \multicolumn{11}{|c|}{ For regressions with expenditure decentralization: } \\
\hline \multirow[t]{2}{*}{ Country } & \multirow[t]{2}{*}{ Period } & \multicolumn{9}{|l|}{ Period average } \\
\hline & & $\begin{array}{l}\text { Exp. } \\
\text { decentralization }\end{array}$ & Deficit/GDP & G & GDPgr & Population & Governance & Local elections & Ethnoling.Frac. & $\begin{array}{l}\text { GNI per capita } \\
\text { (in logs) }\end{array}$ \\
\hline Australia & $1980-97$ & 0.53 & 0.01 & 0.42 & 3.19 & 0.02 & 0.89 & 1 & 0.34 & 9.64 \\
\hline Austria & 1980-94 & 0.42 & 0.05 & 0.54 & 2.21 & 0.01 & 0.87 & 1 & 0.14 & 9.57 \\
\hline Bolivia & $1986-98$ & 0.24 & 0.03 & 0.23 & 3.49 & 0.01 & 0.40 & 1 & 0.73 & 6.67 \\
\hline Brazil & $1980-97$ & 0.42 & 0.07 & 0.40 & 2.63 & 0.15 & 0.49 & 1 & 0.08 & 7.82 \\
\hline Canada & $1980-97$ & 0.70 & 0.04 & 0.56 & 2.34 & 0.03 & 0.89 & 1 & 0.81 & 9.69 \\
\hline Colombia & $1982-86$ & 0.35 & 0.02 & 0.17 & 2.96 & 0.03 & 0.30 & 1 & 0.06 & 7.09 \\
\hline France & $1982-84$ & 0.38 & 0.03 & 0.58 & 1.52 & 0.06 & 0.76 & 1 & 0.28 & 9.25 \\
\hline Germany & 1995-96 & 0.57 & 0.02 & 0.56 & 1.25 & 0.08 & 0.85 & 1 & 0.03 & 10.26 \\
\hline Iran, Islamic Rep. & $1980-89$ & 0.03 & 0.07 & 0.26 & 0.54 & 0.05 & 0.33 & 0 & 0.82 & 8.01 \\
\hline Malaysia & 1985-95 & 0.21 & 0.03 & 0.34 & 6.96 & 0.02 & 0.52 & 1 & 0.77 & 7.84 \\
\hline Mexico & 1980-97 & 0.23 & 0.05 & 0.24 & 2.66 & 0.08 & 0.47 & 1 & 0.32 & 7.96 \\
\hline Portugal & $1987-88$ & 0.07 & 0.08 & 0.38 & 6.94 & 0.01 & 0.78 & 0 & 0.01 & 8.38 \\
\hline South Africa & $1984-85$ & 0.23 & 0.04 & 0.36 & 1.38 & 0.03 & 0.54 & 1 & 0.95 & 7.74 \\
\hline Spain & $1980-97$ & 0.36 & 0.05 & 0.44 & 2.45 & 0.04 & 0.81 & 1 & 0.47 & 9.07 \\
\hline Switzerland & $1980-84$ & 0.73 & 0.00 & 0.39 & 1.66 & 0.01 & 0.95 & 1 & 0.54 & 9.78 \\
\hline United States & 1980-98 & 0.60 & 0.03 & 0.41 & 2.65 & 0.25 & 0.85 & 1 & 0.54 & 9.96 \\
\hline DC average: & & 0.53 & 0.03 & 0.48 & 2.29 & 0.06 & 0.86 & 1.00 & 0.45 & 9.57 \\
\hline LDC average: & & 0.22 & 0.05 & 0.30 & 3.44 & 0.05 & 0.48 & 0.73 & 0.47 & 7.69 \\
\hline \multicolumn{11}{|c|}{ For regressions with revenue decentralization: } \\
\hline \multirow[t]{2}{*}{ Country } & \multirow[t]{2}{*}{ Period } & \multicolumn{9}{|l|}{ Period average } \\
\hline & & $\begin{array}{l}\text { Rev. } \\
\text { decentralization }\end{array}$ & Deficit/GDP & G & GDPgr & Population & Governance & Local elections & Ethnoling.Frac. & $\begin{array}{l}\text { GNI per capita } \\
\text { (in logs) }\end{array}$ \\
\hline Australia & $1980-97$ & 0.28 & 0.01 & 0.42 & 3.19 & 0.02 & 0.89 & 1 & 0.34 & 9.64 \\
\hline Austria & $1980-94$ & 0.27 & 0.05 & 0.54 & 2.21 & 0.01 & 0.87 & 1 & 0.14 & 9.57 \\
\hline Bolivia & 1986-98 & 0.20 & 0.03 & 0.23 & 3.49 & 0.01 & 0.40 & 1 & 0.73 & 6.67 \\
\hline Brazil & 1980-97 & 0.25 & 0.07 & 0.40 & 2.63 & 0.15 & 0.49 & 1 & 0.08 & 7.82 \\
\hline Canada & 1980-97 & 0.53 & 0.04 & 0.56 & 2.34 & 0.03 & 0.89 & 1 & 0.81 & 9.69 \\
\hline Colombia & $1980-86$ & 0.19 & 0.01 & 0.17 & 3.03 & 0.03 & 0.30 & 1 & 0.06 & 7.09 \\
\hline Germany & 1992-98 & 0.33 & 0.02 & 0.55 & 1.51 & 0.08 & 0.85 & 1 & 0.03 & 10.19 \\
\hline Iran, Islamic Rep. & $1980-89$ & 0.05 & 0.07 & 0.26 & 0.54 & 0.05 & 0.33 & 0 & 0.82 & 8.01 \\
\hline Mexico & 1980-98 & 0.21 & 0.04 & 0.24 & 2.78 & 0.08 & 0.47 & 1 & 0.32 & 7.98 \\
\hline Peru & 1990-98 & 0.06 & 0.01 & 0.19 & 4.05 & 0.02 & 0.43 & 1 & 0.63 & 7.36 \\
\hline Portugal & $1987-98$ & 0.06 & 0.05 & 0.44 & 3.58 & 0.01 & 0.78 & 0 & 0.01 & 8.97 \\
\hline South Africa & 1980-98 & 0.13 & 0.04 & 0.38 & 1.82 & 0.04 & 0.54 & 1 & 0.95 & 7.97 \\
\hline Spain & 1980-97 & 0.15 & 0.05 & 0.44 & 2.45 & 0.04 & 0.81 & 1 & 0.47 & 9.07 \\
\hline Switzerland & 1980-98 & 0.45 & 0.00 & 0.46 & 1.51 & 0.01 & 0.95 & 1 & 0.54 & 10.22 \\
\hline United States & 1980-98 & 0.41 & 0.03 & 0.41 & 2.65 & 0.25 & 0.85 & 1 & 0.54 & 9.96 \\
\hline DC average: & & 0.34 & 0.03 & 0.48 & 2.27 & 0.06 & 0.87 & 1.00 & 0.41 & 9.76 \\
\hline LDC average: & & 0.14 & 0.04 & 0.29 & 2.74 & 0.05 & 0.47 & 0.73 & 0.45 & 7.73 \\
\hline
\end{tabular}

Source: based on the sources and author's own calculations reported in Appendix 1. 


\section{Appendix 3. Correlations among the major variables used in the empirical analysis}

\begin{tabular}{|c|c|c|c|c|c|c|c|c|c|c|c|c|c|c|c|c|}
\hline & FDexp & $\begin{array}{l}\text { FDexp- } \\
\text { extreme }\end{array}$ & Fdrev & $\begin{array}{l}\text { FDrev- } \\
\text { extreme }\end{array}$ & $\begin{array}{l}\text { FDexp* } \\
\text { population }\end{array}$ & $\begin{array}{l}\text { FDexp* } \\
\text { governance }\end{array}$ & $\begin{array}{l}\text { FDexp* } \\
\text { local elec. }\end{array}$ & $\begin{array}{l}\text { FDexp* } \\
\text { ethnoling.frac. }\end{array}$ & $\begin{array}{l}\text { FDrev* } \\
\text { population }\end{array}$ & $\begin{array}{l}\text { FDrev* } \\
\text { governance }\end{array}$ & $\begin{array}{l}\text { FDrev* } \\
\text { local elec. }\end{array}$ & $\begin{array}{l}\text { FDrev* } \\
\text { ethnoling.frac. }\end{array}$ & Population & Governance & $\begin{array}{l}\text { Local } \\
\text { elections }\end{array}$ & $\begin{array}{l}\text { Ethnoling. } \\
\text { Frac. }\end{array}$ \\
\hline FDexp & 1.00 & & & & & & & & & & & & & & & \\
\hline FDexp-extreme & 0.09 & 1.00 & & & & & & & & & & & & & & \\
\hline Fdrev & 0.91 & -0.17 & 1.00 & & & & & & & & & & & & & \\
\hline FDrev-extreme & -0.27 & 0.66 & -0.40 & 1.00 & & & & & & & & & & & & \\
\hline FDexp*population & 0.35 & 0.13 & 0.36 & -0.33 & 1.00 & & & & & & & & & & & \\
\hline FDexp* governance & 0.96 & 0.00 & 0.88 & -0.35 & 0.26 & 1.00 & & & & & & & & & & \\
\hline FDexp* local elec. & 0.99 & 0.10 & 0.90 & -0.24 & 0.35 & 0.94 & 1.00 & & & & & & & & & \\
\hline $\begin{array}{l}\text { FDexp* ethnoling. } \\
\text { frac. }\end{array}$ & 0.75 & -0.38 & 0.837 & -0.6 & 0.20 & 0.78 & 0.73 & 1.00 & & & & & & & & \\
\hline FDrev*population & 0.33 & 0.08 & 0.38 & -0.35 & 0.99 & 0.26 & 0.33 & 0.21 & 1.00 & & & & & & & \\
\hline FDrev* governance & 0.92 & -0.17 & 0.96 & -0.46 & 0.28 & 0.96 & 0.91 & 0.85 & 0.30 & 1.00 & & & & & & \\
\hline FDrev*local elec. & 0.92 & -0.13 & 0.99 & -0.35 & 0.36 & 0.88 & 0.93 & 0.80 & 0.38 & 0.95 & 1.00 & & & & & \\
\hline $\begin{array}{l}\text { FDrev* } \\
\text { ethnoling.frac. }\end{array}$ & 0.68 & -0.47 & 0.83 & -0.68 & 0.18 & 0.71 & 0.66 & 0.98 & 0.21 & 0.82 & 0.80 & 1.00 & & & & \\
\hline Population & 0.17 & 0.10 & 0.20 & -0.26 & 0.97 & 0.07 & 0.18 & 0.03 & 0.96 & 0.11 & 0.21 & 0.03 & 1.00 & & & \\
\hline Governance & 0.77 & 0.13 & 0.64 & -0.20 & 0.15 & 0.89 & 0.77 & 0.58 & 0.14 & 0.80 & 0.65 & 0.47 & -0.03 & 1.00 & & \\
\hline Local elections & 0.06 & -0.57 & 0.22 & -0.68 & -0.04 & 0.17 & 0.04 & 0.65 & -0.01 & 0.27 & 0.17 & 0.68 & -0.11 & 0.03 & 1.00 & \\
\hline Ethnoling.Frac. & 0.57 & 0.31 & 0.49 & 0.26 & 0.20 & 0.45 & 0.63 & 0.27 & 0.19 & 0.40 & 0.58 & 0.21 & 0.12 & 0.40 & -0.29 & 1.00 \\
\hline
\end{tabular}

Note: shaded cells indicate correlations that are more than $80 \%$. 
Appendix 4. Panel unit root test results

\begin{tabular}{cllllll}
\hline & DefGDP & GDPgr & G/GDP & FDexp & FDrev & lnGDpc \\
\hline LLC-test: & -1.930 & -11.719 & -2.366 & 0.897 & -0.379 & 0.430 \\
$p$-value & 0.030 & 0.000 & 0.009 & 0.815 & 0.993 \\
& With Linear Trend & & & & -2.478 \\
LLC-test: & -0.193 & -11.456 & -3.885 & -3.064 & -1.792 \\
$p$-value & 0.030 & 0.000 & 0.000 & 0.001 & 0.007 & 2 \\
Optimal lags $\left({ }^{*}\right):$ & 3 & 2 & 2 & 3 & 2 \\
\hline
\end{tabular}

$\left({ }^{*}\right)$ Based on Schwatz Information Criteria.

Appendix 5a. Determining the range of significance for the marginal effect of FDexp ${ }^{*} I_{i j}$ (Dashed lines show the 95\% confidence band)
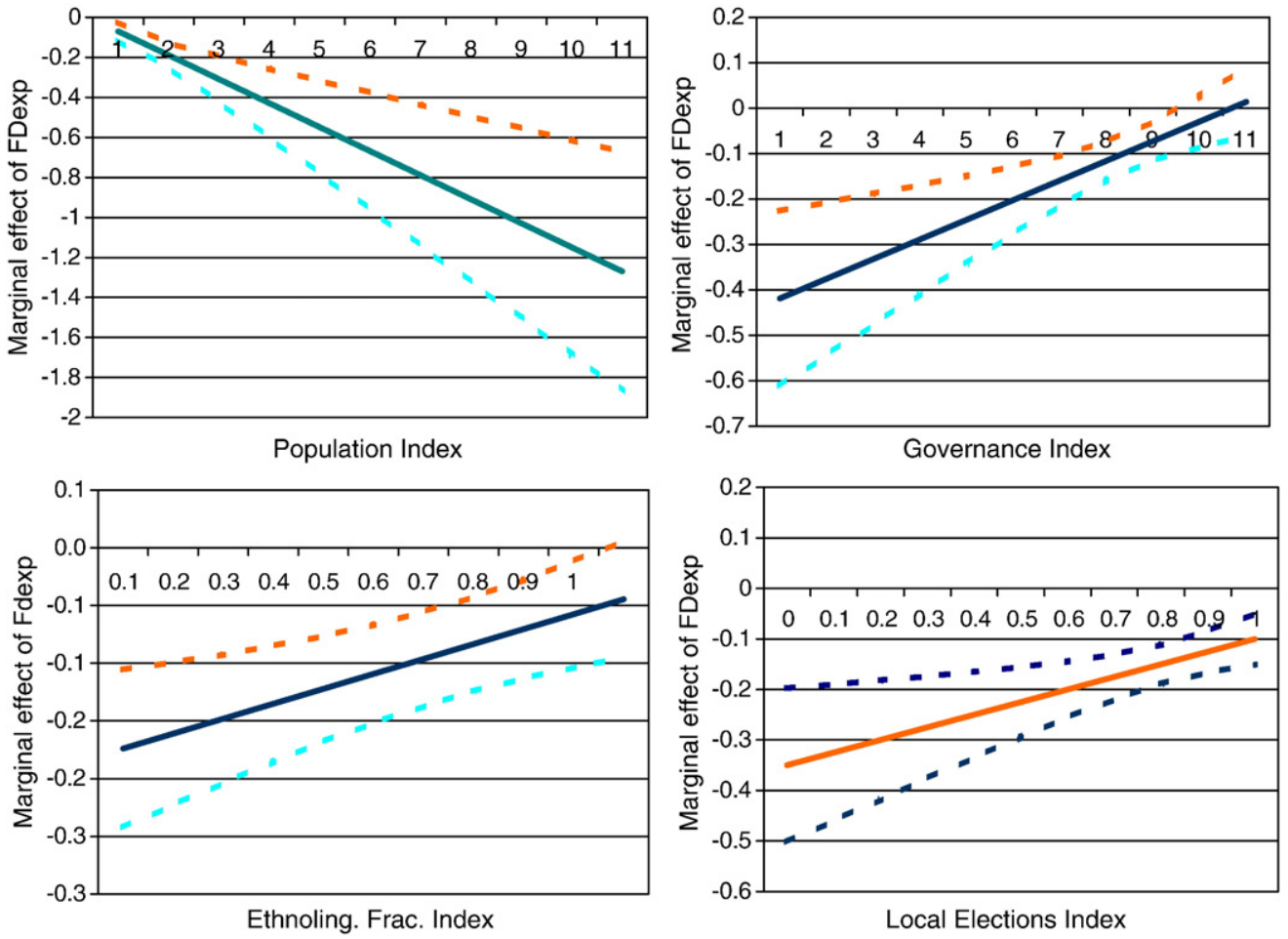
Appendix 5b. Determining the range of significance for the marginal effect of $F D r e v{ }^{*} I_{i j}$ (Dashed lines show the 95\% confidence band)
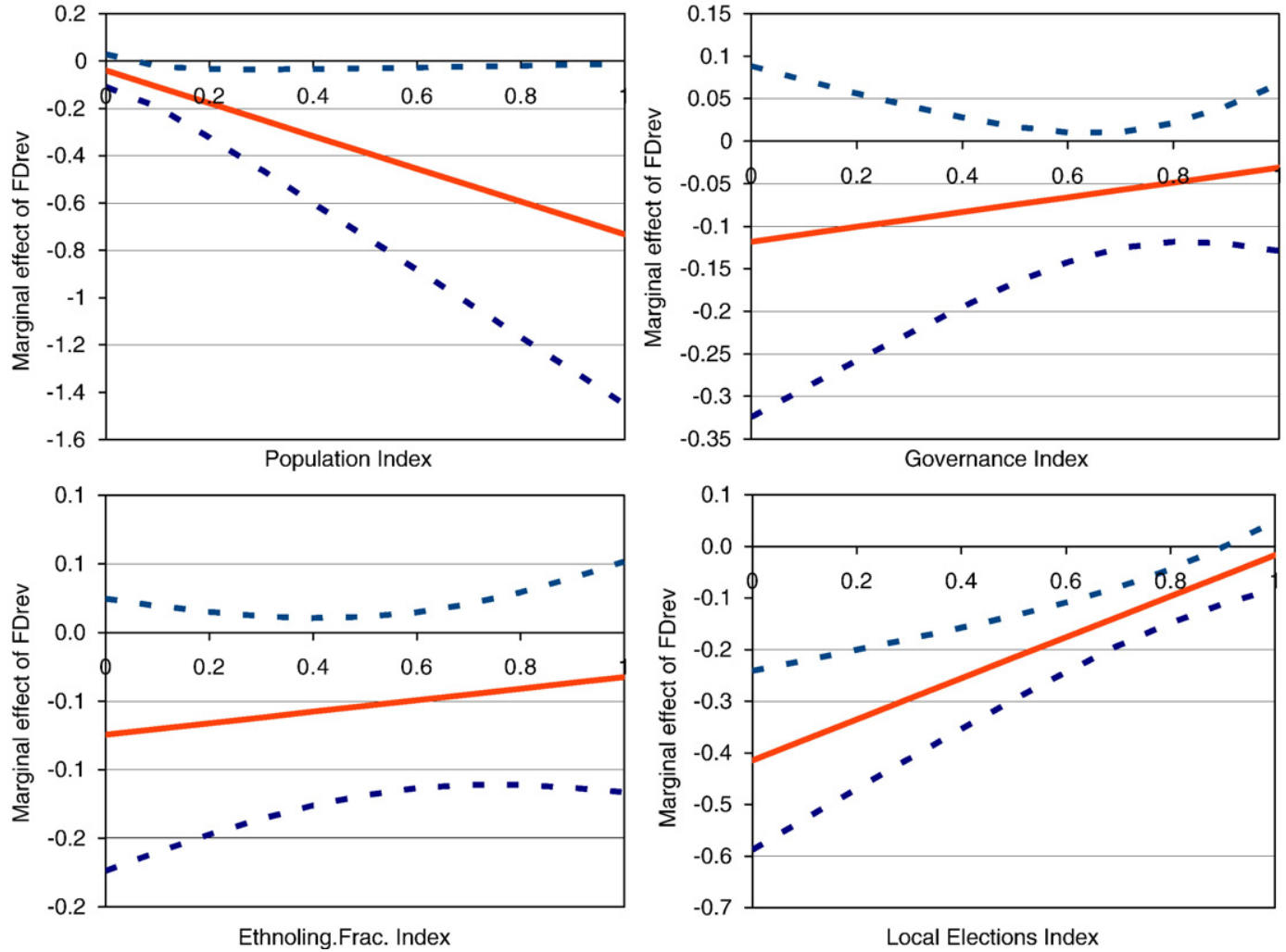

Appendix 6. Comparing FDrev with Stegarescu (2005)'s measures for 1996-2001, where available

\begin{tabular}{lllll}
\hline Country: & RD1 & RD2 & RD3 & \\
\hline Austria & 0.13 & 0.34 & 0.34 & \\
Australia & 0.31 & 0.31 & 0.31 & 0.25 \\
Canada & 0.57 & 0.57 & 0.57 & 0.33 \\
US & 0.47 & 0.47 & 0.47 & 0.53 \\
\hline
\end{tabular}

(Note: RD1, RD2 and RD3 are taken from Figure 3 of Stegarescu, 2005.).

\section{References}

Adam, A., Delis, M.D., Kammas, P., 2008. Fiscal decentralization and public sector efficiency: evidence from OECD countries. CESifo Working Paper Series No. 2364. Baltagi, B.H., 1995. Econometric Analysis of Panel Data. John Wiley and Sons Ltd., Chichester, U.K.

Barrett, B.F.D., 2000. Decentralization in Japan: negotiating the transfer authority. Japanese Studies 20, 33-48.

Beck, T., Clarke, G., Groff, A., Keefer, P., Walsh, P., 2001. New tools in comparative political economy: the database of political institutions. World Bank Economic Review 15, 165-176.

Blanchard, O., Shleifer, A., 2000. Federalism with and without political centralization: China versus Russia. NBER Working Paper No. 7616. National Bureau of Economic Research, Cambridge, MA.

Bouton, L., Gassner, M., Verardi, V., 2008. Redistributing income under fiscal vertical imbalance. European Journal of Political Economy 24, 317-328.

Bradhan, P.K., Mookherjee, D., 1998. Expenditure decentralization and the delivery of public services in developing countries. CIDER Working Paper No. C98-104. Brambor, T., Clark, W.R., Golder, M., 2006. Understanding interaction models: improving empirical analyses. Political Analysis 14, 63-82.

Chen, K., 2004. Fiscal centralization and the form of corruption in China. European Journal of Political Economy 20, 1001-1009.

Davoodi, H., Zou, H., 1998. Fiscal decentralization and economic growth: a cross-country study. Journal of Urban Economics 43, $244-257$.

De Mello, L., 2000a. Can fiscal decentralization strengthen social capital? IMF Working Paper. No. 00/129. International Monetary Fund, Washington D.C.

De Mello, L., 2000b. Fiscal decentralization and intergovernmental fiscal relations: a cross-country analysis. World Development 28, 365-380.

De Mello, L., Barenstein, M., 2001. Fiscal decentralization and governance: a cross-country analysis. IMF Working Paper No. 01/71. International Monetary Fund, Washington D.C.

Dethier, J. (Ed.), 2000. Governance, Decentralization, and Reform in China, India, and Russia. Kluwer Academic Publishers, Boston.

Easterly, W., Levine, R., 1997. Africa's growth tragedy: Policies and ethnic divisions. Quarterly Journal of Economics 111, 1203-1250. 
Eaton, K., 2001. Political obstacles to decentralization: evidence from Argentina and Philippines. Development and Change 32, $101-127$.

Ebel, R.D., Yilmaz, S., 2002. On the measurement and impact of fiscal decentralization. Policy Research Working Paper No.2809. The World Bank, Washington D.C. Faguet, J., 2001. Does decentralization increase responsiveness to local needs? Evidence from Bolivia. Policy Research Working Paper No.2516. The World Bank, Washington D.C.

Feltenstein, A., Iwata, S., 2005. Decentralization and macroeconomic performance in China: regional autonomy has its costs. Journal of Development Economics 76, 481-501.

Fisman, R., Gatti, R., 2002. Decentralization and corruption: evidence across countries. Journal of Public Economics 83, 325-545.

Fleinkman, L., Pleakanov, A., 2005. Fiscal decentralization in rentier regions: evidence from Russia. World Development 37, 503-512.

Goodspeed, T., 2002. Bailouts in a federation. International Tax and Public Finance 9, 409-421.

Greene, W.H., 1993. Econometric Analysis. Macmillan Publishing Co., New York.

Hausman, J.A., 1978. Specification tests in econometrics. Econometrica 46, 1251-1271.

Hillman, A.L., 2009. Public Finance and Public Policy: Responsibilities and Limitations of Government, 2nd ed. Cambridge University Press, New York.

Hope, K.R., 2000. Decentralization and local governance theory and practice in Botswana. Development Southern Africa 17, $519-534$.

Hsiao, C., 1986. Analysis of panel data. Econometric Society Monographs. Cambridge University Press, Cambridge U.K.

Jin, J., Zou, H., 2002. How does fiscal decentralization affect aggregate, national, and subnational government size? Journal of Urban Economics 52, $270-293$.

Kappeler, A., Välilä, T., 2008. Fiscal federalism and the composition of public investment in Europe. European Journal of Political Economy 24, 562-570.

Kaufmann, D., Kraay, A., Zoido-Lobaton, P., 2002. Governance matters II: updated indicators for 2000/01. Policy Research Working Paper No.2772. The World Bank, Washington D.C.

Kennedy, P., 1997. A Guide to Econometrics. The MIT Press, Cambridge, MA.

King, D.N., Ma, Y., 2001. Fiscal decentralization, central bank independence and inflation. Economic Letters 72, 95-98.

Kyriacou, A., Sagales, O.R., 2009. Fiscal descentralization and the quality of government: evidence from panel data. Hacienda Pública Española/Revista de Economía Pública 189, 131-155.

Lin, J.Y., Liu, Z., 2000. Fiscal decentralization and economic growth in China. Economic Development and Cultural Change 49, 1-21.

Maddala, G.S., 1998. Recent developments in dynamic econometric modelling: a personal viewpoint. Political Analysis 7, $59-87$.

Martinez-Vazquez, J., McNab, R.M., 2006. Fiscal decentralization, macrostability and growth. Hacienda Pública Española/Revista de Economía Pública 179, 25-49.

Neyapti, B., 2004. Fiscal decentralization, central bank independence and inflation: a panel investigation. Economics Letters 82, 227-230.

Neyapti, B., 2005. Fiscal decentralization and socio-economic outcomes in Turkey: an empirical investigation. METU Studies in Development 32, $433-465$.

Norris, E.D., Martinez-Vazquez, J., Noregaard, J., 2000. Making decentralization work: the case of Russia, Ukraine and Kazakhstan. ISP Working Paper No. 0009. Georgia State University, Atlanta, GA.

Oates, W., 1972. Fiscal Decentralization. Harcourt Brace Jovanowich, New York

Oates, W., 1993. Fiscal decentralization and economic development. National Tax Journal 46, 237-243.

Panizza, U., 1999. On the determinants of fiscal centralization: theory and evidence. Journal of Public Economics 74, 97-139.

Samuelson, P.A., 1954. The pure theory of public expenditure. Review of Economics and Statistics 36, 387-389.

Stegarescu, D., 2005. Public sector decentralization: measurement concepts and recent international trends. Fiscal Studies 26, $301-333$.

Stegarescu, D., 2009. The effects of economic and political integration on fiscal decentralization: evidence from OECD countries. Canadian Journal of Economics 42 , 694-718.

Tanzi, V., 2000. On fiscal federalism: issues to worry about. Conference Notes, Conference on Fiscal Decentralization, IMF, Fiscal Affairs Department, Washington D.C. Tanzi, V., 2008. The future of fiscal federalism. European Journal of Political Economy 24, 7105-7112.

Tanzi, V., 2009. The future of fiscal federalism and global governance: a reply to Roland Vaubel. European Journal of Political Economy 25, $137-139$.

Thiessen, U., 2003. Fiscal decentralization and growth in high-income OECD countries. Fiscal Studies 24, $237-274$.

Treisman, D., 2000. Decentralization and the quality of government. Unpublished paper. Department of Political Science, University of California at Los Angeles.

Vaubel, R., 2009. The future of fiscal federalism and global governance: a response to Vito Tanzi. European Journal of Political Economy $25,133-136$.

Von Braun, J., Grote, U., 2002. Does decentralization serve the poor? IMF, Fiscal Decentralization, Routledge Economics, Washington D.C. , pp. 92-119.

Wasylenko, M., 1987. Fiscal decentralization and economic development. Public Budgeting and Finance 7, 57-71.

Zhang, X., 2006. Fiscal decentralization and political centralization in China: implications for growth and inequality. Journal of Comparative Economics 34,

$713-726$ 